\title{
PENEGAKAN HUKUM TINDAK PIDANA INSUBORDINASI DALAM \\ MILITER (STUDI KASUS PUTUSAN PM NOMOR: 94-K/PM.III- 12/AD/VI/2015)
}

\author{
Anuar Bukhari \\ (Mahasiswa Program S1 Fakultas Hukum Universitas Tarumanagara) \\ (E-mail: anuar bukhari@yahoo.co.id)
}

\section{Muhammad Abudan, S.H., M.H.}

(Corresponding Author)

(Dosen Fakultas Hukum Universitas Tarumanagara. Meraih Sarjana Hukum (S.H.) dari Fakultas Hukum Universitas 17 Agustus Jakarta (1987), Magister Hukum (M.H.) dari Fakultas Hukum Universitas Indonesia (2007)).

(E-mail: mabindano@gmail.com)

\begin{abstract}
Insubordination is a criminal act against a superior committed by a TNI soldier, during office hours or outside office hours on condition that the superiors get an official order to carry out their duties or represent the company unit. Insubordination crimes is an act that is not justified among the military, because it is considered to have violated the Sapta Marga and oath of warriors which are the basis of personality patterns as TNI soldiers. In this research, there are a several of issues, first about what is an insubordination crime, and the second is how law enforcement and judges considerations in deciding an insubordination case. The research method used by the author is normative legal research. The results of the study found that law enforcement of TNI soldiers committing an insubordination criminal act is the same as law enforcement of other criminal acts carried out by military members, what distinguishes it is the court's power in the matter of prosecuting at the first level, if the defendant is a Captain down to be tried through a Military Court. Meanwhile, the defendants with the rank of Major and above were tried through the High Military Court. Judges' considerations in deciding on this insubordination case are guided by Articles 103 to 109 of the Indonesian Military Penal Code, as well as the evidence gathered in the trial, in addition, thoroughness, carefulness, and wisdom of the judge is also highly prioritized, to avoid making mistakes in decision.
\end{abstract}

Keywords: Military Crime, Insubordination, TNI Soldier. 


\section{PENDAHULUAN}

\section{A. Latar Belakang}

Tentara Nasional Indonesia (TNI) merupakan alat pertahanan negara yang memiliki tugas untuk melaksanakan kebijakan pertahanan negara dalam hal menegakkan kedaulatan negara, mempertahankan keutuhan wilayah, melindungi keselamatan bangsa, menjalankan operasi militer untuk perang dan operasi militer selain perang, serta ikut secara aktif dalam tugas pemeliharaan perdamaian baik lingkup nasional maupun internasional. Istilah militer berasal dari bahasa Yunani yaitu "milies" yang memiliki arti orangorang yang dipersiapkan dan ditugaskan untuk perang. Prajurit TNI disiapkan untuk melaksanakan tugas menjaga keamanan dan keselamatan segenap bangsa dari ancaman militer, serta ancaman lain terhadap keutuhan bangsa dan negara. Prajurit TNI diberikan fasilitas oleh negara untuk memakai senjata atau bertempur, serta dilatih dan dididik untuk mematuhi perintahperintah, arahan dan putusan dengan cara yang efisien dan efektif. ${ }^{1)}$

Setiap warga negara memiliki kedudukan yang sama dihadapan hukum, guna mencapai hal tersebut maka diperlukan adanya kerja sama antara negara dan warga negara. Negara sebagai pemegang kekuasaan memberi tugas dan fungsi kepada perangkat negara dan aparat penegak hukum serta elemenelemen lainnya untuk kemudian dipatuhi oleh warga negara dengan demikian dapat mewujudkan tercapainya kestabilan nasional.

Guna mewujudkan kehidupan masyarakat yang aman, tentram, tertib, dan sejahtera pemerintah selaku cerminan negara wajib secara konsisten untuk mengontrol, mengawasi dan menertibkan aparat penegak hukum agar menjadi aparatur yang baik, bersih, tegas dan berwibawa yang ketika melaksanakan tugasnya selalu berlandaskan aturan hukum dan senantiasa menjaga dan melindungi hak-hak masyarakat.

Prajurit merupakan orang yang sengaja dilatih, dibina, dan dipersiapkan untuk bertempur. Maka bagi prajurit diterapkan norma-norma atau kaidahkaidah khusus. Para prajurit harus tunduk dan patuh pada peraturan yang telah ditentukan dan pelaksanaannya diawasi dengan ketat. Displin

1) Patresia Pivitha, "Pelaksanaan Ketentuan Pasal 106-109 KUHPM tentang Insubordinasi di Pengadilan Militer II-11 Yogyakarta”, Journal UAJY, (Januari 2016): hlm. 2. 
merupakan wujud nyata dari sikap mental seseorang untuk mentaati secara mutlak lahir dan batin tanpa keterpaksaan, dilakukan secara ikhlas dan bertanggung jawab. Disiplin prajurit pada dasarnya ialah bentuk kepatuhan yang didasarkan atas kesadaran lahiriah maupun batiniah seorang prajurit serta pengabdian kepada bangsa dan negara, dan bentuk wujud pengelolaan diri agar tidak melanggar perintah kedinasan dan aturan-aturan yang berlaku dalam kehidupan militer. Dengan demikian disiplin prajurit adalah syarat mutlak yang harus ditaati dalam kehidupan prajurit Tentara Nasional Indonesia yang diwujudkan ketika menjalankan tugasnya dengan berlandaskan pada iman dan taqwa kepada Tuhan Yang Maha Esa serta pengorbanan bagi nusa dan bangsa. ${ }^{2)}$

Dalam kehidupan militer, disiplin harus dimiliki dengan penuh keyakinan, patuh dan taat, loyal terhadap atasan dengan berpegang teguh kepada sendisendi yang telah tertuang di dalam sapta marga dan sumpah prajurit. Diantara sikap atau pernyataan keluar yang harus nampak ialah: (1) Kerapihan dalam sikap serta tindakan (2) Kebersihan dan kerapian dalam pakaian serta perlengkapan (3) Rasa hormat kepada atasan (4) Kerelaan dan kecermatan di dalam melaksanakan tugas, contoh yaitu pada saat melaksanakan perintah kedinasan. Apabila hal-hal tersebut terpenuhi, maka sudah dapat dinilai ada atau tidaknya disiplin tersebut dalam diri masing-masing prajurit.

Apabila diamati dari segi hukum, anggota militer memiliki derajat yang setara dengan anggota masyarakat lainnya, artinya sebagai warga negara baik anggota militer maupun masyarakat dapat diberlakukan segala aturan hukum positif yang ada, baik itu hukum pidana, hukum perdata, hukum acara pidana, hukum acara perdata dan lainnya. Perbedaannya yaitu terdapat peraturan yang bersifat khusus terhadap anggota militer yang lebih keras dan lebih berat ancaman hukumannya dibanding masyarakat biasa, hal itu dikarenakan adanya beberapa perbuatan yang memang hanya dapat dilakukan oleh anggota militer dan tidak dapat dilakukan oleh masyarakat umum, misal:

2) Marchel Imanuel Padang, "Tinjauan Tarhadap Penjatuhan Sanksi Bagi Anggota TN1 yang Melakukan Tindak Pidana 1nsubordinasi”, Journal UAJY, (Januari 2017): hlm.1. 
mengabaikan perintah dinas, menentang atasan (insubordinasi), disersi (meninggalkan satuan) dsb.

Contoh kasus insubordinasi yang terjadi beberapa tahun terakhir ini yaitu anggota TNI Angkatan Laut Denpasar, berpangkat Kopral Dua, diduga membunuh atasannya, berpangkat Sersan Dua. Penyebabnya diperkirakan karena cuti tahunan yang tidak diberikan satuannya. ${ }^{3)}$ Selain itu terdapat juga kasus insubordinasi yang terjadi di belahan dunia lain, yaitu di negara Rusia dimana warga negara disana dilatih dan dididik untuk mengikuti kegiatan wajib militer akan tetapi, sebagian diantaranya menolak dan mengabaikan perintah tersebut lalu mengambil suatu langkah licik yang bertentangan dengan hukum dengan menyuap atasannya.

Tindakan-tindakan sebagaimana yang disebutkan di atas mencerminkan sikap anggota militer yang tidak beretika, mengabaikan perintah dan melanggar norma-norma hukum yang berlaku. Seorang prajurit seharusnya wajib mematuhi perintah atasan dan berada di kesatuan secara terus menerus sepanjang waktu dinasnya dan tidak diperbolehkan untuk menolak apalagi menentang perintah kedinasan. Jika ia berhalangan atau berkeinginan untuk meninggalkan kesatuan karena suatu keperluan maka harus mendapat persetujuan terlebih dahulu dari atasan, sesuai dengan aturan-aturan yang berlaku pada lingkungan TNI.

Merupakan suatu keharusan pada kehidupan militer untuk menegakkan aturan-aturan serta perintah kedinasan dari setiap atasan demi menegakkan kehidupan militer yang disiplin dan penuh kesadaran tinggi. Jika hal-hal tersebut dilanggar dengan sengaja dan penuh kesadaran juga, maka itu menunjukan anggota militer yang tidak baik dan tidak bertanggung jawab di dalam menegakkan Sapta Marga dan Sumpah Prajurit, apabila dibiarkan maka akan menggoyahkan sendi-sendi kehidupan disiplin dan ketertiban di lingkungan TNI.

Diperlukan hukum yang bersifat khusus terhadap anggota militer, karena jika dilihat beberapa perbuatan yang bersifat berat sedemikian rupa, jika

3) Bram Setiawan, "Prajurit TNI Bunuh Atasan di Bali Mulai Disidangkan," https://nasional.tempo.co/read/823954/prajurit-tni-bunuh-atasan-di-bali-mulaidisidangkan/full\&view=ok, diakses tanggal 25 Mei 2018. 
dilakukan oleh anggota militer di dalam ranah tertentu, dari segi hukum pidana umum ancaman hukumannya dirasa teramat ringan. Contohnya saja seorang anggota militer yang melakukan pencurian senjata di dalam kompi atau markas militer, dalam hukum pidana umum tidak mengatur mengenai pencurian yang dilakukan oleh anggota militer terhadap barang atau alat persenjataan milik negara, akan tetapi hanya mengatur mengenai barang atau kepunyaan milik orang lain dengan sengaja, dalam pidana umum ancaman hukumannya paling lama ialah selama lima tahun, sementara dalam hukum pidana militer ancamannya bisa lebih berat yaitu selama tujuh tahun, oleh karena itu dengan adanya aturan khusus hukum pidana militer maka dapat mengakomodir permasalahan hukum yang terjadi di dalam negeri baik itu oleh warga negara maupun alat kelengkapan negara.

Militer mempunyai ketentuan-ketentuan lain dalam penegakkan hukum yaitu adanya Peradilan Ketentaraan atau Peradilan Militer sehingga diberlakukan hukuman khusus yang lebih berat. Berkaitan dengan hal tersebut terdapat sebuah aturan yang mengatur mengenai kompetensi Peradilan Militer yaitu terdapat pada Pasal 3 Ayat (4) Ketetapan MPR Nomor VII/MPR/2000 tentang Peran Tentara Nasional Indonesia dan Peran Kepolisian Negara Republik Indonesia. Bacharudin mengemukakan bahwa apabila ketentuan Pasal 3 Ayat (4) huruf a Ketetapan MPR No. VII/MPR/2000 diterapkan, maka perkara-perkara yang menjadi kompetensi Peradilan Militer ialah (1) semua tindak pidana yang diatur dalam KUHPM; (2) tindak pidana umum yang dilakukan oleh anggota TNI dalam dinas militer; (3) tindak pidana umum yang dilakukan oleh anggota TNI dalam markas, kesatrian, asrama dan kapal/pesawat; dan (4) tindak pidana umum yang dilakukan oleh prajurit dalam keadaan darurat militer dan keadaan perang. ${ }^{4)}$

Peradilan Militer sebagai suatu badan peradilan yang memeriksa dan mengadili tidak berpuncak dan diawasi oleh Mabes TNI atau Dephankam, akan tetapi Peradilan Militer berpuncak dan diawasi oleh Mahkamah Agung.

4) Nikenn Subakti dan Sapriyadi, "Yurisdiksi Peradilan Terhadap Prajurit Tentara Nasional 1ndonesia Sebagai Pelaku Tindak Pidana", Journal Yustisia, Volume 3, Nomor 2 (Mei 2014): hlm. 105. 
Setiap anggota TNI dituntut untuk sebersih "kertas putih" dari perbuatan pribadi yang tercela baik di mata para anggota TNI sendiri maupun di kalangan masyarakat. Setiap anggota TNI dituntut pula menegakkan kehormatan dan berupaya untuk menjauhi tindakan yang dapat mencederai nama baik ketentaraan. Perbuatan atau tindakan apa saja yang diperbuat oleh prajurit TN1 baik itu sendiri-sendiri ataupun bersama-sama yang melanggar aturan hukum, melangar norma-norma yang berlaku dalam masyarakat atau bertentangan dengan aturan kedinasan, disiplin, tata tertib di lingkungan TNI pada dasarnya merupakan perbuatan yang dapat merusak wibawa, kehormatan dan nama baik TNI yang apabila perbuatan atau tindakan itu dibiarkan terus, dapat menimbulkan ketidak-tentraman dalam masyarakat dan menghambat pelaksanaan pembangunan dan pembinaan TNI. ${ }^{5)}$

Berkaitan dengan anggota TNI yang melanggar ketentuan-ketentuan hukum, maka hukum militer mengenal berbagai macam hukuman yang dapat diterapkan terhadap anggotanya, yaitu hukum pidana sipil dan hukum pidana militer. Bahwasannya hukum pidana sipil ini berlaku juga bagi anggota TNI, antara lain sebagaimana yang tercantum dalam Pasal 1 KUHP menyatakan bahwa aturan-aturan umum termasuk juga bab IX KUHP pada umumnya berlaku dalam menggunakan KUHPM. Menurut Pasal 2: jika perbuatan yang dilakukan oleh seorang yang tunduk pada KUHPM namun tidak tertuangkan di dalamnya, maka yang digunakam perbuatan pidana yang tertuang pada KUHP.)

Pada kasus insubordinasi, Peradilan Militer dan Peradilan Umum berbeda dalam tahap penyelesaiannya serta aturan yang digunakan cenderung berbeda meski sama-sama mengatur mengenai insubordinasi. Dalam KUHP insubordinasi diatur dalam Pasal 459-461, sementara pengaturan khususnya diatur dalam Pasal 106-109 KUHPM. Lain halnya dengan pidana biasa jika terjadi pemukulan atas seseorang sehingga menyebabkan luka maka dapat diancam dengan pidana penganiayaan, dan harus ada pengaduan sebelumnya dari korban atau pihak keluarga yang merasa dirugikan. Sementara pada

5) Haryo Sulistiriyanto, "Pertanggungjawaban Pidana Anggota Militer TN1 yang Melakukan Tindak Pidana Dessersi”, Journal Perspektif, Volume XVI, Nomor 2 (April 2O11): hlm. 85.

6) Moeljatno, Asas-Asas Hukum Pidana (Edisi Revisi), (Jakarta: Rineka Cipta, 2008), hlm.22. 
kasus insubordinansi yang dilakukan oleh prajurit TNI maka perkara itu akan diselesaikan melalui pengadilan lewat pengaduan langsung dari korban dan atau laporan dari atasan yang berhak menghukum (Ankum).

Pada kasus melawan perintah atasan terdapat unsur-unsur yang dapat membuat seorang anggota TNI didakwa dengan Pasal tindak pidana insubordinasi yaitu Pasal 106 KUHPM, unsur kesatu yakni sebagai anggota militer, yang kedua perbuatan yang dilakukan dengan sengaja dan nyata, dan unsur selanjutnya bahwa bawahan melakukan penyerangan terhadap atasannya dengan kekerasan sehingga mengabaikan pekerjaan dinasnya. Maksudnya ialah bahwa setiap bawahan harus menghormati atasannya, atasan disini tidak hanya atasan langsung tetapi setiap prajurit TNI yang karena pangkat dan/atau jabatannya berkedudukan lebih tinggi dari prajurit TNI yang lain.

Adanya suatu keharusan yakni setiap anggota TN1 diwajibkan untuk mematuhi dan melaksanakan titah atasannya sehingga memunculkan adanya tingkat perbedaan antara atasan dan bawahan atau dalam kehidupan militer antara komdan dan prajurrit. Selain itu pula apabila seorang anggota TN1 melakukan insubordinansi ialah sesuatu yang ganjil, melihat strukturisasi di militer yang mewajibkan prajurit harus hormat dan taat kepada perintah atasan, maka peneliti tertarik untuk melakukan penelitian yang berjudul: “Penegakan Hukum Tindak Pidana Insubordinasi dalam Militer (Studi Kasus Putusan PM Nomor: 94-K/PM.III-12/AD/VI/2015)".

\section{B. Perumusan Masalahan}

Berdasarkan latar belakang masalah sebagaimana yang dikemukakan di atas maka rumusan masalahnya ialah:

1. Apa itu tindak pidana insubordinasi?

2. Bagaimana penegakan hukum dan pertimbangan hakim dalam memutus perkara insubordinasi Nomor: 94-K/PM.III-12/AD/VI/2015 Apakah sudah sesuai dengan ketentuan hukum yang berlaku?

\section{Metode Penelitian}


Penlitian hukum adalah suatu kegiatan ilmiah yang didasarkan pada metode, sistematika dan pemikiran tertentu, yang bertujuan untuk mempelajari satu atau beberapa gejala hukum tertentu dengan jelas menganalisanya. ${ }^{7)}$ Menurut Soerjono Soekanto, metodologi merupakan suatu unsur yang mutlak harus ada di dalam penelitian dan pengembangan suatu ilmu pengetahuan. ${ }^{8)}$

Terdapat 2 (dua) metode dalam melakukan penelitian hukum, yaitu penelitian hukum normatif dan penelitian hukum empiris. Jenis penelitian yang digunakan dalam penelitian ini adalah penelitian hukum normatif, yaitu penelitian yang mengkaji hukum tertulis dari berbagai faktor, yaitu faktor teori, sejarah, perbandingan, struktur dan komposisi, lingkup dan materi, konsistensi, penjelasan umum, dan pasal demi pasal. Jenis penelitian hukum normatif menurut Soerjono Soekanto pada dasarnya penelitian normatif meneliti menegenai implementasi ketentuan hukum normatif (undangundang) dalam aksinya pada setiap peristiwa hukum tertentu yang terjadi dalam suatu masyarakat.

1. Tipe Penelitian

Berdasarkan pada permasalahan yang diteliti, maka tipe penelitian yang digunakan adalah penelitian hukum normatif. Yaitu penelitian yang mengkaji hukum tertulis dari berbagai aspek, yaitu aspek teori, sejarah, perbandingan, struktur dan komposisi, lingkup dan materi, konsistensi, penjelasan umum, dan pasal demi pasal.

2. Spesifikasi Penelitian

Penelitian ini bersifat deskriptif analitis, yang mengungkapkan peraturan perundang-undangan yang berkaitan dengan teori-teori hukum yang menjadi objek penelitian. Demikian juga hukum dalam pelaksanaannya di dalam masyarakat yang berkenaan dengan objek penelitian. ${ }^{9)}$

3. Jenis dan Sumber Bahan Data

7) Soerjono Soekanto, Pengantar Penelitian Hukum, (Jakarta : UI Press, 1986), hlm. 43.

8) Ibid., hlm. 7.

9) Zainuddin Ali, Metode Penelitian Hukum, (Jakarta: Sinar Grafika, 2010), hlm. 106. 
Pada penelitian hukum normatif, jenis data yang pertama digunakan adalah data sekunder. Data sekunder adalah data yang diperoleh dari hasil penelaahan kepustakaan atau penelaahan terhadap berbagai literatur atau bahan pustaka yang berkaitan dengan masalah atau materi penelitian yang sering disebut sebagai bahan hukum. ${ }^{10)}$ Data sekunder yang dipergunakan adalah data sekunder yang bersifat umum, yaitu data yang berupa tulisan-tulisan, data arsip, data resmi dan berbagai data lain yang dipublikasikan. ${ }^{11)}$ Data sekunder dalam penelitian ini, terdiri dari:

a. Bahan hukum primer, yaitu meliputi peraturan perundang-undangan dan ketentuan yang berkaitan dengan penelitian ini yaitu:

1) Kitab Undang-Undang Hukum Pidanaa (KUHP);

2) Kitab Undang-Undangg Hukum Pidana Militer (KUHPM);

3) Undang-Undang Republik Indonesia Nomor 31 Tahun I997 tentang Perradilan Militer;

4) Undang-Undang Republik Indonesia Nomor 34 Tahun $2 \mathrm{O} 04$ tentang Tentara Nasional Republik Indonesia;

5) Undang-Undang Republik Indonesia Nomor 25 Tahun $2 \mathrm{O} 14$ tentang Hukum Disiplin Militer;

6) Putusan Pengadilan Militer Nomor 94-K/PM.III$12 / \mathrm{AD} / \mathrm{VI} / 2 \mathrm{O} 15$.

b. Bahan hukum sekunder, yaitu menjelaskan akan hukum primer. Pada penelitian ini bahan hukum sekunder yang digunakan adalah buku dan literatur yang berhubungan dengan materi yang berkaitan sebagai referensi penulisan serta bahan dari internet.

c. Bahan hukum tersier, yaitu memberikan petunjuk terhadap bahan hukum primer dan sekunder. Bahan hukum tersier yang digunakan adalah Kamus Besar Bahasa Indonesia serta apabila diperlukan wawancara dengan para pihak yang terkait.

10) Mukti Fajar dan Yulianto Ahmad, Dualisme Penelitian Hukum dan Empiris, (Yogyakarta: Pustaka Pelajar, 2010), hlm. 156.

11) Soerjono, Op.Cit., hlm. 51. 
Setelah segala sesuatunya dianggap memadai, dengan bekal tersebut penulis melakukan penelitian lapangan untuk mendapatkan data primer dengan melakukan wawancara kepada berbagai pihak yang kompeten memberikan informasi.

4. Teknik Pengumpulan Data

Teknik pengumpulan data terdiri dari:

a. Teknik Penelitian Kepustakaan (Library Research)

Data kepustakaan yang didapat melalui penelitian kepustakaan yang bersumber dari peraturan perundang-undangan, buku-buku, dokumen resmi, publikasi, dan hasil penelitian.

b. Teknik Penelitian Lapangan

Data lapangan yang diperlukan sebagai data penunjang diperoleh melalui wawancara atau mencari informasi dan pendapat-pendapat dari responden yang ditentukan secara purposive sampling (ditentukan oleh peneliti berdasarkan kemauannya) dan/atau random sampling (ditentukan oleh peneliti secara acak). ${ }^{12)}$

5. Teknik Analisis Data

Teknik analisis data yang digunakan dalam penelitian ini adalah teknik atau metode analisis bahan hukum kualitatif menggunakan model Miles \& Huberman, yaitu dilakukan melalui pengorganisasian data, membaginya ke dalam satuan-satuan, kemudian melaksanakan program sintesa, menyusunnya ke dalam suatu bentuk pola, lalu memilih bahan yang dianggap utama dan mana yang akan diteliti, diawali dari sebelum peneliti menjamah lapangan, diteruskan saat peneliti telah masuk di lapangan secara interaktif dan berlangsung kontinyu sampai selesai sehingga datanya jenuh. Kejenuhan data dapat dilihat dengan tidak didapatkannya lagi data atau informasi baru.

Analisis data menggunakan model Miles \& Huberman, memliki skema sebagai berikut: 


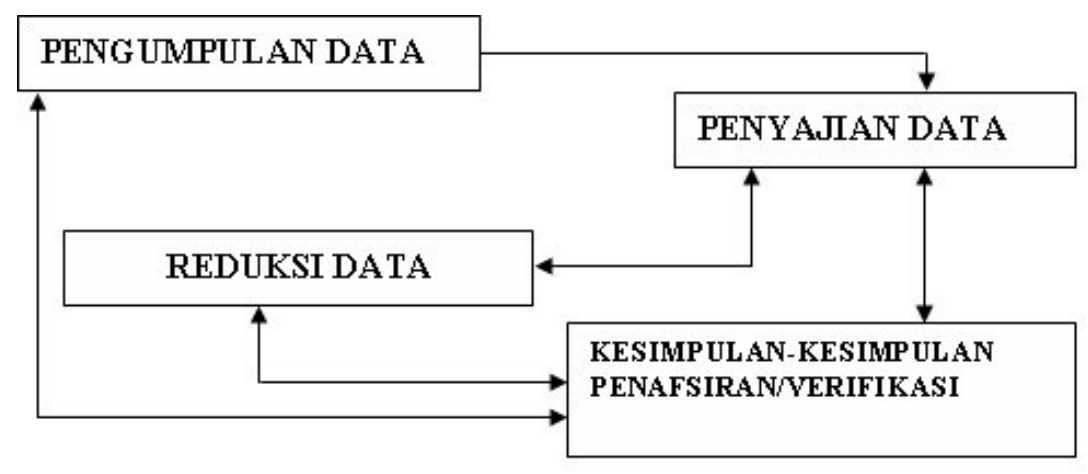

\section{PEMBAHASAN}

\section{A. Prolog}

Insubordinasi merupakan tindak pidana melawan atasan yang dilakukan oleh prajurit TNI di saat jam dinas, maupun diluar jam dinas dengan syarat atasan tersebut mendapatkan surat perintah dinas untuk mengemban tugas atau mewakili kompi kesatuannya. Tindak pidana insubordinasi marak sekali terjadi di kalangan TNI, baik itu pola dan cara melakukannya. Insubordinasi merupakan perbuatan yang sangat tidak dibenarkan dikalangan militer, karena dianggap telah melanggar sapta marga dan sumpah prajurit yang menjadi dasar acuan pola kepribadian sebagai prajurit TNI. Perbuatan melawan atasan tidak seharusnya dilakukan di lingkungan militer. lantaran, tindakan melawan atasan atau insubordinasi tergolong kategori tindak pidana berat. Terhadap prajurit yang terbukti melakukan perbuatan tersebut, maka akan ditindak secara tegas dan dapat dikenakan sanksi yang tegas. Tidak dipungkiri manusia selaku makhluk sosial, selalu mempunyai hasrat untuk bersosialisasi, berkomunikasi dan berhubungan dengan sesama manusia, begitupun halnya dengan anggota TNI. Akan tetapi dalam tahapan bersosialisasi dan bergaul tersebut tidak selalu berjalan dengan mulus, ada kalanya terjadi persinggungan, ketidak cocokan bahkan perselisihan yang berakibat terjadinya tindak pidana insubordinasi atau tindakan melawan atasan. Tindak Pidana Insubordinasi bisa dihindari apabila setiap anggota TNI selalu berpedoman pada peraturan disiplin prajurit, terutama yang berkaitan dengan relasi antara atasan dan bawahan. "Berdasarkana Surat Keputusan Panglima 
TNI No. : Kep/22/VIII/2005 tanggal 10 Agustus 2005 tentang Peraturan Disiplin Prajurit TNI, telah mengatur kedudukan antara atasan dan bawahan dalam kehidupan dinas maupun di luar dinas". sebagaimana tercantum dalam Peraturan Disiplin Prajurit TNI, Bab III, Pasal 18, yaitu, setiap bawahan harus tunduk serta patuh kepada atasan, serta menjunjung tinggi segala perintah dinas dan arahan yang diberikan oleh atasan, berdasarkan kesadaran yang tinggi bahwa setiap perintah dan arahan tersebut untuk kepentingan kedinasan; Bersikap hormat terhadap atasan, baik di dalam maupun di luar kedinasan, berdasarkan kesadaran untuk menegakkan kehormatan prajurit; Memegang teguh dan menjaga sikap, perkataan dan perbuatan pada waktu berhadapan dengan atasan, baik di dalam maupun di luar pekerjaan dinas.

Insubordinasi atau tindak pidana menentang atasan, apabila tidak kunjumg diselesaikan secara cepat maka akan berdampak kepada satuan, sehingga dapat menimbulkan keguncangan di dalam TNI, oleh karena itu selain aturanaturan yang telah dimuat di dalam pengaturan disiplin prajurit, semua prajurit harus memaknai dan meresapi kembali Permildas (Peraturan Militer Dasar) secara mendalam sehingga memiliki kesadaran yang tinggi dalam menjalankan tugas sehari-hari. Selain itu diharapkan juga kepada setiap perwira bisa menguasai dan mampu menjalankan aturan dan ketentuanketentuan yang belaku di lingkungan TNI tanpa cacat. Dalam skripsi ini ada beberapa permasalahan yang ada, pertama mengenai apa yang dimaksud dengan tindak pidana insubordinasi, dan yang kedua bagaimana penegakan hukum serta pertimbangan hakim dalam menjatuhkan sanksi kepada anggota militer yang malakukan tindaak pidana insubordinansi. Dengan mengacu pada rumusn masaalah yang ada, maka metode penelitian yang digunakan adalah normatif, yaitu penelitian hukum yang mengkaji studi dokumen untuk mencari bahan hukum sekunder, dan pendekatan yang dipakai ialah pendekatan kualitatif prespektif yang menghasilkan logika berpikir dan cara menyelesaikan permasalahan yang ada.

\section{B. Kasus Posisi}


Pada kasus tindak pidana insubordinasi yang dilakukan oleh prajurit TNI di wilayah hukum Pengadilan Militer Yogyakarta dalam nomor perkara 94K/PM.III-12/AD/VI/2015, yang mana identitas Terdakwa dalam surat dakwaan adalah sebagai berikut:

Nama Lengkap
Pangkat / NRP
Jabatan
Kesatuan
Tempat, Tanggal Lahir
Jenis Kelamin
Kewarganegaraan
Agama
Tempat Tinggal

: Bagus Suharto

: Kopka / 3920214240870

: Tamudi Munisi Yonarmed 8/1/2 Kostrad

: Yonarmed 8/1/2 Kostrad

: Mojokerto, 26 Agustus 1970

: Laki-laki

: Indonesia

: Islam

: Asrama Yonarmed 8/1/2 Kostrad Jember

Dengan korban sebagaimana tertera di dalam surat dakwaan Oditur adalah sebagai berikut:

\begin{tabular}{|c|c|}
\hline Nama Lengkap & : I Gusti Nyoman Sudarma \\
\hline Pangkat / NRP & : Lettu Arm / 39200363580372 \\
\hline Jabatan & : Danton Kom Raima sekarang Gumil Gol \\
\hline Kesatuan & $\begin{array}{l}\text { VIII Depsista Pusdik Armed } \\
\text { : Yonarmed } 81112 \text { Kostrad sekarang Pusdik }\end{array}$ \\
\hline & Armed Bandung \\
\hline Tempat, Tanggal Lahir & : Bali, 12 Maret 1972 \\
\hline Jenis Kelamin & : Laki-laki \\
\hline Kewarganegaraan & : Indonesia \\
\hline Agama & : Hindu \\
\hline Tempat Tinggal & : Asrama Yonarmed 81112 Kostrad Jember \\
\hline
\end{tabular}

Cibeber Cimahi

Pada hari Senin tanggal 17 November 2014 sekitar pukul 08.15 WIB setelah pasukan Yonarmed 8/1/2 Kostrad selesai melaksanakan upacara Korban sekaligus Saksi-1 merapat ke Kompi markas yang pada saat itu Kompi markas sedang diambil alih oleh Saksi-2 yaitu Batih Rai Serka I Wayan Rai Mudana dan pasukan tersebut dibagi atas 20 (dua puluh) personil kemudian anggota tersebut diperintahkan untuk menyilangkan senjata dan selanjutnya anggota diarahkan ke lapangan basket untuk latihan PBB tanpa senjata, kemudian Saksi-1 Lettu Arm I Gusti Nyoman Sudarma menerima 
telepon dari Komandan Batrai Kapten Arm Sugeng agar melatih ulang peragaan karena akan ditinjau langsung oleh Danyon Armed Mayor Arm Bayu Argo Asmoro dan memerintahkan anggota latihan PBB untuk latihan menggunakan senjata, kemudian Saksi-1 menyampaikan kepada Batih Rai markas yaitu Saksi-2 agar senjata yang disilangkan segera diambil dan melanjutkan latihan PBB bersenjata, pada saat anggota sedang mengambil senjata kecuali Terdakwa setelah mengambil senjata kemudian balik kanan dan memisahkan diri dari personel lainnya yang akan mengikuti latihan peragaan PBB dan mengarah ke kantor Batera markas, setelah itu Saksi-1 memanggil Terdakwa "Pak Bagus mau kemana sampean, kumpul dulu" akan tetapi panggilan Saksi-1 tersebut tidak didengar oleh Terdakwa kemudian Saksi-1 mengulangi panggilan tersebut akan tetapi kembali tidak didengar oleh Terdakwa, kemudian Saksi-1 bertanya kepada Saksi-2 selaku Batih Rai markas "Batih, Pak Bagus itu mau kemana" dan dijawab oleh Saksi-2 "tidak tau Danton" kemudian Saksi-1 memanggil terdakwa lagi namun kembali tidak dihiraukan setelah itu Saksi-1 mendatangi tempat Terdakwa dan Saksi-1 berkata "Pak Bagus dengar tidak yang saya sampaikan tadi, kumpul dulu" dan dijawab oleh Terdakwa "saya mau makan" dan Terdakwa balik kanan mendekati Saksi-1 selanjutnya Saksi-1 menyampaikan kepada Terdakwa dengan suara agak keras "Pak Bagus sampean dengar apa tidak perintah saya, kumpul dulu!" dan dijawab oleh Terdakwa "Apa kamu memangnya saya takut sama kamu!" dan Saksi-1 jawab "Pak Bagus mau menantang saya?!" dan kembali dijawab oleh Terdakwa “Ayo kalau berani!" setelah terdakwa berucap seperti itu kepada Saksi-1 kemudian Saksi-1 dengan reflek menampar pipi sebelah kiri Terdakwa dengan menggunakan tangan kanan. Tidak lama kemudian Terdakwa menyerang Saksi-1 dengan menggunakan senjata FNC yang dipegangnya kemudian ditangkis oleh Saksi-1 lalu datang anggota lainnya membantu melerai merebut senjata yang dipegang oleh Terdakwa, kemudian Terdakwa mencabut sangkur pistolnya dari pinggang kanan Terdakwa dengan menggunakan tangan kirinya kemudian Saksi-1 berbalik dan melihat Terdakwa mengacungkan sangkur sambil berkata kepada 
Saksi-1 "Tak bunuh kamu” dan mengancam Saksi-1 dengan perkataan "Awas kamu tidak kena disini lihat saja nanti diluar" dan tidak lama kemudian Serma Suraji selaku Saksi-3 memisahkan Saksi-1 dengan Terdakwa selanjutnya Danrai markas mengajak Saksi-1 ke kantor Batalyon markas.

\section{Hasil Wawancara}

1. Bapak Boedhi Prasetyo S.H., M.H Selaku Dosen Hukum Pidana /

\section{Hukum Militer}

Sebagaimana hasil wawancara yang penulis lakukan dengan Bapak Boedhi Prasetyo, maka terdapat beberapa poin-poin yang penulis masukkan sesuai dengan penulisan skripsi ini. Berbicara mengenai penegakan hukum maka berbicara tentang hukum acara, proses beracara diawali dari proses penyelidikan, penyidikan, pemeriksaan sidang di pengadilan sampai dengan keputusan hakim. Hakim memutuskan perkara melihat dari dua sisi yaitu dari sisi pelaku berkaitan dengan tindak pidana yang dilakukan dan dari sisi korban dilihat dari akibat yang timbul oleh tindak pidana tersebut. Perkara insubordinasi termasuk kategori tindak pidana berat, mengapa dikatakan berat? Karena ancaman hukumannya sebagaimana yang diatur oleh undang-undang yaitu di atas lima tahun. Untuk mengetahui suatu tindak pidana itu ringan atau berat maka dapat dilihat di dalam Undang-Undang Hukum Disiplin Militer. Jika tindak pidana tersebut termasuk kategori tindak pidana ringan, maka ancaman hukumannya di bawah 3 bulan, dan terhadap pelaku akan diadili melalui sidang disiplin militer bukan melalui sidang di Peradilan Militer.

Faktor yang menyebabkan seorang prajurit melakukan tindak pidana insubordinasi dapat disebabkan oleh berbagai macam hal, diantaranya:

a. Perbedaan perlakuan atau sikap, ketika seorang atasan memberi perlakuan berbeda atau melakukan tindakan semena-mena terhadap bawahan.

b. Perbedaan usia, dalam dunia militer seorang atasan bisa saja memiliki usia yang lebih muda daripada bawahannya, maka dapat 
timbul rasa kecemburuan sosial sehingga menyebabkan seseorang melakukan tindak pidana insubordinasi.

c. Faktor pelecehan secara verbal, dengan menggunakan kata-kata kasar seperti "kamu pangkat kopral saja sok-sokan kerjamu le'lean!”. Ucapan kata-kata seperti itu dapat memancing timbulnya emosi sehingga menyebabkan bawahan melawan dan menyerang atasannya.

Hal-hal sebagaimana yang disebutkan diatas merupakan contoh-contoh faktor yang memicu seorang prajurit melakukan tindak pidana insubordinasi.

2. Bapak Satiman S.H., M.H Selaku Panmud Pidana Pengadilan Militer

Terdapat beberapa faktor yang menjadi pertimbangan hakim dalam memutus perkara insubordinasi, seperti perbuatan pidana yang dilakukan secara berulang kali, hakim akan menjatuhkan hukuman berat apabila prajurit yang melakukakan insobordinasi kemudian diketahui telah melakukan perbuatan pidana juga sebelumnya.

Dalam hal ini salah satu faktor yang menjadi pertimbangan hakim dalam memutus perkara adalah faktor sebab akibat. Misal, seorang atasan menghukum bawahannya karena kesalahan yang telah diperbuat, hukuman yang diberi berupa tindakan kekerasan secara fisik, pada saat atasan tersebut memukul bawahannya mendadak bawahannya reflek/kaget dengan respon memukul balik atasannya, tanpa sengaja mengenai bagian vital tubuh atasan, maka oleh karena perbuatan itu atasan meninggal dunia, maka dalam hal ini tindakan bawahan terhadap atasannya tidak dapat dikategorikan sebagai perbuatan pembunuhan dengan sengaja sebagaimana yang diatur dalam KUHP yang ancaman hukumannya lima belas tahun penjara, akan tetapi perbuatan tersebut dikategorikan sebagai perbuatan pembunuhan karena faktor ketidaksengajaan, sehingga hukuman yang diberikan oleh hakim bisa lebih ringan daripada hukuman semestinya yang diatur oleh perundangundangan. Dalam hal ini, hakim diberi kebebasan dan terlepas dari 
intervensi pihak manapun dalam memutus perkara dan tetap berpedoman pada aturan yang berlaku.

Upaya yang bisa dilakukan untuk meminimalisir tindak pidana insubordinasi yang terjadi di indonesia yaitu dengan dilakukannya sosialisasi dan penyuluhan kepada prajurit-prajurit TNI di seluruh indonesia, saat ini pun sosialisasi sudah berjalan yaitu yang dilakukan oleh corps, batalyon atau satuan-satuan yang membidangi masalah berkaitan dengan pelanggaran-pelanggaran serta tindak pidana yang terjadi di TNI, yakni ialah corps bagian hukum, satuan ini memberikan informasi kepada prajurit mengenai bahaya, dampak serta sanksi yang akan diterima apabila anggota TNI melakukan pelanggaran, kejahatan dan tindak pidana militer, contoh yang sering terjadi: (narkotika, desersi, asusila, penganiayaan) sanksinya bisa berupa penurunan pangkat, pidana penjara hingga pemecatan dan pencabutan hak sebagai anggota militer secara tidak terhormat. Selain itu dilakukannya juga rapat komite secara massif setiap bulan yang bertujuan untuk menyamakan persepsi antara satuan serta membahas mengenai perkembangan penyelesaian kasus, faktor-faktor yang menjadi kendala untuk kemudian dicarikan solusinya secara bersama.

3. Bapak Gagan Hertawan S.H., M.H Selaku Kapok Oditurat Militer

Dalam hal penegakan hukum perkara insubordinasi maka proses yang dilalui sama dengan penegakan hukum perkara pidana lainnya yang terdakwanya ialah anggota militer, artinya tetap diproses berdasarkan hukum yang berlaku di lingkungan militer dan disidangkan di Pengadilan Militer selaku pengadilan tingkat pertama di lingkungan militer.

Sejalan dengan ketentuan undang-undang, bapak gagan selaku Kepala Kelompok Oditurat Militer Jakarta menyetujui bahwa tindakan insubordinasi yang terjadi di lingkungan militer tidak seharusnya ada dan perbuatan tersebut tidaklah dibenarkan baik dari segi hukum maupun norma-norma yang berlaku dalam kehidupan. Namun, apabila terjadi maka tindakan insubordinasi yang dilakukan secara nyata akan 
memperberat hukuman si terdakwa, terlebih jika akibat dari perbuatannya tersebut mengakibatkan atasan terluka atau bahkan meninggal dunia.

Oleh karena itu hukuman yang diterima oleh anggota militer yang melakukan tindak pidana insubordinasi seharusnya berat, mengingat bahwa insubordinasi termasuk dalam kategori tindak pidana berat, hukuman yang diberikan tidak hanya berupa hukuman badan (penjara) akan tetapi juga hukuman administrasi dan hukuman secara sosial, seperti penundaan kenaikan pangkat, penundaan kesempatan untuk melanjutkan sekolah/studi, penundaan kenaikan gaji, tidak mendapatkan remon, dsb. Itu semua cukup menjadi suatu pukulan bagi si prajurit itu sendiri. Beliau menambahkan bahwa rasa keadilan dalam penegakkan hukum militer seharusnya tidak hanya dimiliki oleh seorang hakim, akan tetapi oditur juga sebelum melakukan penuntutan harus memiliki rasa keadilan yang bersumber dari hati nurani masing-masing.

\section{Analisis}

Berdasarkan dialog diatas dan berdasarkan aturan yang berlaku maka penulis berpendapat bahwa tindakan yang dilakukan oleh atasan sudah benar dan sesuai dengan aturan, meskipun tindakan penamparan yang dilakukan oleh atasan dikatakan sebagai penyebab terjadinya insubordinasi dalam kasus ini, akan tetapi tindakan atasan tersebut telah sesuai dengan hukum dan atasan berupaya untuk menegakkan Hukum Disiplin Militer. Bahwasannya atasan boleh melakukan tindakan fisik kepada bawahan dalam rangka mendidik, membina supaya bawahan tersebut disiplin, taat dan tunduk terhadap perintah. Atas dasar ini atasan boleh melakukan tindakan fisik kepada bawahannya, akan tetapi bawahan tidak boleh membalasnya karena apabila bawahan membalas atau bahkan menyerang atasannya maka tindakan itu termasuk dalam kategori Tindak Pidana Insubordinasi.

Berdasarkan Pasal 26 Undang-Undang Nomor 25 Tahun 2014 tentang Hukum Disiplin Militer. Bahwa setiap atasan berwenang memberi Tindakan Disiplin Militer terhadap setiap bawahannya yang melakukan pelanggaran Hukum Disiplin Militer. Tindakan Disiplin Militer dapat diberikan secara 
langsung oleh setiap atasan kepada bawahannya dengan berupa tindakan fisik dan/atau teguran lisan yang bersifat mendidik dan bertujuan untuk mencegah terulangnya Pelanggaran Hukum Disiplin Militer.

Penulis berpendapat bahwa putusan yang diberikan oleh hakim tergolong ringan, mengapa penulis berpendapat demikian, karena jika merujuk pada ketentuan yang mengatur mengenai tindak pidana insubordinasi yaitu di dalam Kitab Undang-Undang Hukum Pidana Militer (KUHPM) insubordinasi tergolong kedalam kategori tindak pidana berat karena ancaman hukumannya yaitu di atas 5 (lima) tahun penjara, sebagaimana yang diatur dalam pasal 106 KUHPM yang berbunyi :

Ayat (1) "Militer, yang dengan sengaja dan tindakan nyata, menyerang seorang atasan, melawannya dengan kekerasan atau ancaman kekerasan, merampas kemerdekaannya untuk bertindak, ataupun memaksanya dengan kekerasan atau ancaman kekerasan untuk melakukan atau menghindar dari suatu pekerjaan dinas, diancam karena insubordinasi dengan tindakan nyata dengan pidana penjara maksimal sembilan tahun"

Ayat (2) "Jika perbuatan itu menyebabkan luka, maka diancam dengan pidana penjara maksimal sepuluh tahun"

Ayat (3) "Jika perbuatan itu menyebabkan kematian, maka diancam dengan penjara maksimal dua belas tahun"

Dalam dunia militer dikenal asas komando dimana hubungan antara atasan dan bawahan sangat terikat pada asas ini. Dimana terdakwa selaku bawahan seharusnya mampu menunjukan sikap patuh dan taat kepada atasannya akan tetapi perbuatan Terdakwa dalam kasus ini sebaliknya dimana Terdakwa menunjukkan sikap arogan dengan mengabaikan perintah bahkan meyerang atasannya. Terdakwa terkesan meremehkan ketentuan yang berlaku di lingkungan militer. Perbuatan Terdakwa dapat merusak citra dan wibawa atasan, dan secara tidak langsung merusak tatanan hierarki yang harus selalu di junjung tinggi dalam kedinasan dan kehidupan militer. Selain itu, Terdakwa telah terbukti bersalah dan selama menjalani proses pemeriksaan di persidangan, tidak ditemukan adanya alasan pemaaf ataupun alasan pembenar 
pada diri Terdakwa, sehingga penulis berpendapat sekaligus mengkritisi bahwa hukuman yang dijatuhkan oleh hakim seharusnya bisa di atas lima bulan atau mungkin dapat di atas satu tahun. Sebab apabila mengacu pada pertimbangan-pertimbangan yang disampaikan oleh majelis hakim dalam amar putusan maka isi dari pertimbangan tersebut sangat memungkinkan terhadap terdakwa untuk dapat dihukum dengan hukuman yang lebih berat.

\section{PENUTUP}

\section{A. Kesimpulan}

1. Tindak Pidana Insubordinasi merupakan tindak pidana yang dilakukan oleh anggota militer yang dengan sengaja dan tindakan nyata, menyerang atau melawan atasan dengan kekerasan atau ancaman kekerasan, merampas kemerdekaannya untuk bertindak ataupun memaksa dengan kekerasan untuk melaksanakan atau mengabaikan suatu pekerjaan dinas, baik disaat jam dinas, maupun diluar jam dinas dengan syarat atasan tersebut mendapatkan surat perintah dinas untuk mengemban tugas atau mewakili kompi kesatuannya. Tindak Pidana Insubordinasi termasuk dalam kategori tindak pidana berat karena memiliki ancaman hukuman yaitu di atas lima tahun.

2. Penegakan hukum anggota militer yang berbuat Tiindak Pidans Insubordinansi sama halnya dengan penegakan hukum terhadap tindaak piidana lainnya yang dilakukan oleh anggota militer, yang membedakannya ialah kekuasaan pengadilan dalam hal mengadili pada tingkat pertama, apabila terdakwanya berpangkat Kapten ke bawah diadili melalui Pengadilan Militer, sementara untuk terdakwa yang berpangkat Mayor ke atas didaili melalui Pengadilan Militer Tinggi. Pertimbangan Hakim dalam memutus perkara insubordinasi telah sesuai dengan ketentuan hukum yang berlaku. Dalam perkara insubordinasi ini hakim berpedoman pada Pasal 103 sampai 109 KUHPM, serta buktibukti yang terkumpul dalam persidangan sebagai acuannya. Akan tetapi dalam membuat putusan Hakim harus memperhatikan segala aspek, mulai dari perlunya kehati-hatian, dihindari sekecil mungkin ketidakcermatan, baik yang bersifat formal maupun materiil. Oleh karena 
B. Saran

itu hakim tidak dapat berbuat sesuka hatinya dalam memutus perkara, melainkan hakim juga harus mempertanggung jawabkan putusannya. Disamping itu, pertimbangan-pertimbangan hakim haruslah berkaitan erat dengan putusan yang akan diberikan hal ini bertujuan agar tidak terjadinya kontradiksi di dalam putusan, sehingga dapat memberikan rasa keadilan bagi terdakwa dan juga korban.

1. Terhadap Hakim dan Oditur apabila menerapkan sanksi pidana dan membuat sebuah dakwaan terhadap pelaku tindak pidana insubordinasi harus dengan sangat memperhatikan aturan yang berlaku, terlebih kepada Oditur, Oditur harus berpedoman pada aturan, sebab percuma apabila aturan memuat ancaman hukuman yang berat akan tetapi tidak pernah digunakan oleh Oditur dalam mendakwa, rata-rata Oditur hanya mendakwa pidana penjara di bawah satu tahun terhadap pelaku tindak pidana insubordinasi, artinya hal ini tidak jauh berbeda dengan dakwaan yang diberi terhadap pelaku tindak pidana lainnya yang tergolong ringan, oleh karena itu jika hal ini terus terjadi maka menurut penulis sebaiknya dilakukan revisi terhadap pasal yang mengatur Tindak Pidana Insubordinasi dalam KUHPM, atau dilakukannya sebuah sosialisasi atau koordinasi kepada seluruh Oditur Militer yang ada di Indonesia untuk menyamakan visi dan misi sebagai upaya untuk tidak mengabaikan aturan hukum yang berlaku.

2. Penulis menyarankan agar kedepannya hubungan antara atasan dan bawahan harus berjalan sebagaimana mestinya, atasan harus lebih dekat dengan bawahan, dan bawahan harus selalu hormat kepada atasan, sehingga upaya preventif dalam menanggulangi tindak pidana insubordinasi dapat terwujud.

3. Terhadap prajurit TNI agar tidak terjerumus kedalam Tindak Pidana Insubordinasi maka harus menanamkan sikap Disiplin Prajurit yaitu dengan cara menghayati Sumpah Prajurit dan Sapta Marga yang berlaku di lingkungan militer, dan mengetahui hukuman yang berlaku apabila melakukan tindak pidana insubordinasi dengan memetik pelajaran dari 
rekannya terdahulu yang pernah terkena hukuman atas tindakan insubordinasi yang dilakukan.

\section{DAFTAR PUSTAKA}

\section{A. Buku}

Ali, Zainuddiin. Metode Penelitian Hukum. (Jakarta: Sinar Grafika, 2O10).

Badudu, J.S. dan Sutan Mohammad Zain. Kamus Besar Bahasa Indonesia, Edisi Kedua. (Jakarta: Balai Pustaka, 1995).

Faisal Salaam, Moch. Peradilan Militer 1ndonesia. (Bandung: CV Mandar Maju, 2004). Maju, 2006).

. Hukum Pidana Militer di Indonesia. (Bandung: CV Mandar

Fajar, Mukti dan Yulianto Ahmad. Dualisme Penelitian Hukum dan Empiris. (Yogyakarta: Pustaka Pelajar, 2010).

Fuady, Munir. Teori-Teori Besar Dalam Hukum. (Jakarta: Kencana Prenada Media Group, 2013).

Hadisoeprapto, Hartono. Pengantar Tata Hukum Indonesia. (Jakarta: Liberti, 2001).

Hakimm, Lukman. Filosofi Kewenangan Organ dan Lembaga Daerah. (Malang: Setara Press, 2O12).

HS, H Salim dan Erlies Septiana Nurbani. Penerapan Teori Hukum Pada Penelitian Tesis dan Disertasi. (DJakarta: RajaGrafindo Persada, 2013).

Maramis, Frans. Hukum Pidana Umum Dan Tertulis Di 1ndonesia. (Jakarta: RajaGrafindo Persada, 2013).

Moeljatno. Asas-Asas Hukum Pidana (Edisi Revisi). (Jakarta: Rineka Cipta, 2008).

Mulyani, Lilik. Kapita Selekta Hukum Pidana Kriminologi dan Victimologi. (Jakarta: Djambatan, 2004). 
Prodjodikoro, Wirjono. Asas-Asas Hukum Pidana di Indonesia. (Bandung: Refika Aditama, 2003).

Santoso, Topo dan Eva Achjani Zulfa. Kriminologi. (Jakarta: RajaGrafindo Persada, 2001).

Sianturi, S.R. Hukum Pidana Militer di Indonesia. (Jakarta: Badan Pembinaan Hukum Tentara Nasional Indonesia, 2010).

Soekanto, Soerjono. Pengantar Penelitian Hukum. (Jakarta : UI Press, 1986). - Faktor-Faktor yang Mempengaruhi Penegakan Hukum. (Jakarta: PT RajaGrafindo Persada, 2011).

Soekanto, Soerjono dan Sri Mamudji. Penelitian Hukum Normatif. (Jakarta: PT RajaGrafindo Persada, 2014).

Zaidan, M. Ali. Kebijakan Kriminal. (Jakarta: Sinar Grafika, 2016).

\section{B. Perundang-undangan}

Kitab Undang-Undang Hukum Pidana Militer (KUHPM).

Indonesia. Undang-Undang Nomor 31 Tahun 1997 tentang Peradilan Militer (Lembaran Negara Republik Indonesia Tahun 1997 Nomor 84).

Indonesia. Undang-Undang Nomor 34 Tahun 2004 tentang Tentara Nasional Indonesia (Lembaran Negara Republik Indonesia Tahun 2004 Nomor 127).

Indonesia. Undang-undang Nomor 25 Tahun 2014 tentang Hukum Disiplin Militer (Lembaran Negara Republik Indonesia Tahun 2014 Nomor 257).

\section{Sumber Lain: Jurnal / Laporan Penelitian dll.}

Fakultas Hukum Universitas Tarumanagara, Peraturan Dekan Nomor 023D/FH-UNTAR/III/2014. Pedoman Penulisan Skripsi Fakultas Hukum Universitas Tarumanagara. (Jakarta: FH-UNTAR, 2014).

Herdjito. Disparitas Penjatuhan Pidana Dalam Perkara Tindak Pidana Desersi. (Penelitian Puslitbang Hukum Dan Peradilan Badan Litbang Diklat KUMDIL Mahkamah Agung, 2014). 
Imanuel Padang, Marchel. Tinjauan Terhadap Penjatuhan Sanksi Bagi Anggota TNI yang Melakukan Tindak Pidana Insubordinasi. (Yogyakarta: Journal UAJY, 2017).

Pivitha, Patresia. Pelaksanaan Ketentuan Pasal 106-109 KUHPM tentang Insubordinasi di Pengadilan Militer II-11 Yogyakarta. (Yogyakarta: Journal UAJY, 2016).

Siangturi S.R. Pengenalan dan Pembangunan Hukum Militer Indonesia. "Pidato (sebagai Lektor Kepala) pada Dies Natalis Ke-32 Akademi Hukum Militer-Perguruan Tinggi Hukum Militer”, (Jakarta: Alumni AHAEM-PETEHAEM, 1985).

Subekti, Niken dan Supriyadi. Yurisdiksi Peradilan Terhadap Prajurit Tentara Nasional Indonesia Sebagai Pelaku Tindak Pidana. (Journal Yustisia, 2014).

Sulistiriyanto, Haryo. Pertanggungjawaban Pidana Anggota Militer TNI yang Melakukan Tindak Pidana Desersi. (Journal Perspektif, Volume XVI No.2, 2011).

Utomo, Edi. Kewenangan Atasan Yang Berhak Menghukum (ANKUM) Sebagai Penyidik Dalam Sistem Peradilan Militer. (Journal Al'Adl, Volume No.1, 2018).

\section{Website}

Setiawan, Bram. "Prajurit TNI Bunuh Atasan di Bali Mulai Disidangkan." https://nasional.tempo.co/read/823954/prajurit-tni-bunuh-atasan-di-balimulai-disidangkan/full\&view=ok. Diakses tanggal 25 Mei 2018. 